"Industrial Revolutions and their impact on managerial practice: Learning from the past"

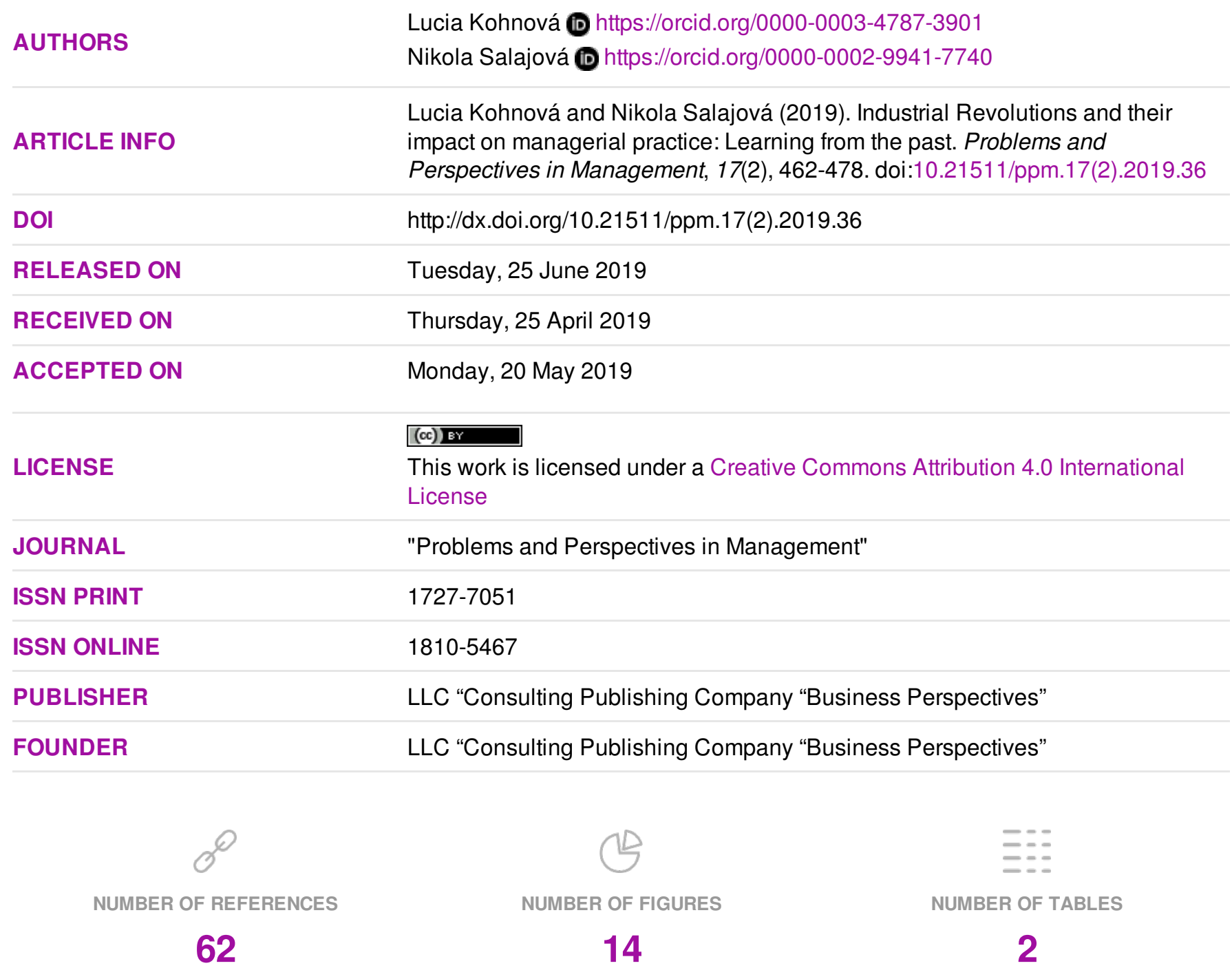

(C) The author(s) 2023. This publication is an open access article. 


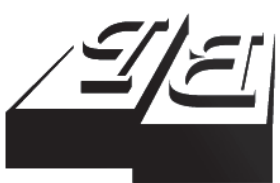

BUSINESS PERSPECTIVES

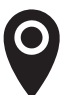

LLC "CPC "Business Perspectives" Hryhorii Skovoroda lane, 10, Sumy, 40022, Ukraine

www.businessperspectives.org

Received on: $25^{\text {th }}$ of April, 2019 Accepted on: $20^{\text {th }}$ of May, 2019

(C) Lucia Kohnová,

Nikola Salajová, 2019

Lucia Kohnová, Ph.D., Faculty of Management, Comenius University in Bratislava, Slovak Republic.

Nikola Salajová, Ph.D. Student, Faculty of Management, Comenius University in Bratislava, Slovak Republic.

\section{INDUSTRIAL REVOLUTIONS AND THEIR IMPACT ON MANAGERIAL PRACTICE: LEARNING FROM THE PAST}

\begin{abstract}
Technological changes that come with industrial revolution have largely affected businesses, as well as society. With the current technological shift and Fourth Industrial Revolution, many questions arise regarding the impacts and effects on current ways businesses operate. This study presents a retrospective analysis and overview of previous industrial revolutions. The aim of the retrospective analysis is to identify common characteristics that may lead to lessons learned for the forthcoming Fourth Industrial Revolution and thus complement the current debate on technological change. All previous industrial revolutions have led to change in business environments and new challenges for managers and owners. The findings show that all previous revolutions have led to increase in the number of service jobs created. The key approach of successful countries during the times of industrial revolution has included education as the source of new skills and knowledge necessary for adaption. Countries that were able to produce high skilled people could not only invent, but also adapt to new technologies sooner than others. Similarly, these approaches included introduction of new managerial practices in order to be able to utilize new technologies and new skilled workers effectively. The research article processes secondary data together with literature review on this topic.
\end{abstract}

\section{Keywords}

\section{JEL Classification}

industrial revolution, employment, skills, organizational change, education, technologies, transformation

\section{INTRODUCTION}

Already in the 18th century, factories began to emerge, employing many people. Before that, people mostly made products in homes using hand tools or simple machines, not knowing the technologies that would make it easier for them to work (Eden, 2018). The First Industrial Revolution as the most important development in human history has been shaping the world together with following revolutions and technological changes (Stearns, 2012). Basic principles of industrial revolutions were tight to new inventions, technologies such as machines and new production systems. However, the critical question arising with new technologies during Second or Third Industrial Revolution was how will the organization change and what will be the impacts of such change. Similarly, to the times of previous revolutions, these questions arise regarding the current, Forth Industrial Revolution (Tortorella \& Fettermann, 2017). While literature on this topic is largely focused on technology adaptation, increase in productivity, efficiency, supply chains or process design (Agostini \& Filippini, 2019), we see a missing perspective on the possible links among industrial revolutions and thus specific predictions of development regarding organizational practice and management. This topic is important due to the fact that each of the industrial revolutions has created new 
environments that owners and directors of companies had to handle. Thus, it is possible to see development of management theory as the reaction on the problems of new systems in new environments (e.g. (Fayol, 1916; Taylor, 1911). This paper aims to examine the specifics of previous industrial revolutions and identify common characteristics and developments. The paper complements the theory by identifying links and common developments in the history of revolutions and thus complements the current discussion on the forthcoming industrial revolution by introducing possible lessons, which may be the focus of future research.

\section{LITERATURE REVIEW}

The First Industrial Revolution, dated from the 18th to the 19th century, started in Britain. Industrialization has been widespread especially in western countries, but has spread beyond the West in the second phase of the revolution. Industrialization meant a transition to powered, special machines, factories and mass production. The development of steam engine, iron and textile industry also played a major role. The new machines were expensive and even owners of small factories had to have the capital to continue operating the company. They accumulated capital through partnerships (Papula \& Papulova, 2014), loans from banks or joint stock companies. With the growth of production, investments had to be made as well to sustain the growth (Mathias, 2001). Relatively small businesses prevailed in this period. Small shops have replaced the traveling peddlers. Industrialization has brought increased volume and variety of products, improved living standards. On the other hand, it has led to grim working and living conditions for the poor and working classes. Unskilled workers did not have the job security and it was easy to replace them with qualified workers. During the First Industrial Revolution, the working hours were very long and the workers did not have much free time (Stearns, 2012). First Industrial Revolution was further characterized by regional diversities, which led to differences in expansion of industries in regions together with differences in wages (Deane, 2000).

The period of the Second Industrial Revolution is defined by the years from 1870 to 1914 (Mokyr \& Strotz, 2000). It was characteristic for capital-intensive production, productivity and living standards and formation of large corporate hierarchies (Jensen, 1993). In particular, the major innovations were affected by communication and transport, which allowed goods to be transported from the
US to the Atlantic and vice versa (Chandler, 1990). The transport revolution has opened up new markets for agriculture, industry, and banking. The factories were not new to the Second Industrial Revolution, but technology, material and management in factories were innovated. Organizational changes in the Second Industrial Revolution were based on more expensive technology equipment, the economy allowed businesses to increase production, and technological change caused larger businesses to employ thousands of workers. It was a period of extremes, which led for a while to overcapacity and partial recessions. Within this period, markets were sustained by mergers and acquisitions in 1890s, which allowed the marginal facilities to be closed (Lamoreuax, 1985). In this era, those who built societies lived in wealth, while most of their employees earned pennies and lived in poverty. There has been an economic uncertainty that has taken millions of people to work or cut wages. Low-skilled workers in the industry did not have safe working conditions, worked for long hours at low wages, and had no pensions (Perkin, 1996). Production was increasingly carried out by the machines themselves, with unskilled workers pulling the lever or turning the valve. However, skilled workers received high wages and oversaw production processes. The economy in the Second Industrial Revolution required technical skills rather than workshop ownership.

Stearns (2012) considered the Third Industrial Revolution (TIR) as the most dramatic, which began to form in the 1960s. This revolution was characteristic for technological innovation of electronics and IT for automation and production. Communication accelerated, business contacts moved to new levels. This revolution has created thousands of businesses and millions of jobs, laying the foundation for globalization in the 21st century. Businesses had to invest in new technologies to succeed in the labor market. The transition 
to the Third Industrial Revolution also required a massive retraining of staff at a professional level. The new workforce in new technologies has had to be technology-qualified and hundreds of other technical fields. Entrepreneurs and managers also had to go through training to use new business models, strategies to know the logistics and supply chains. The skill level of a manager in a TIR was qualitatively differentiated from that of a manager in a Second Industrial Revolution (Rifkin, 2012). All industrial revolutions had some features in common. Revolutions have seen massive technological and organizational changes, redefining the function of the family, changing the nature of work and leisure (Stearns, 2012).

\subsection{Organizational changes between industrial revolutions}

According to Kuznets (1973), major changes through revolutions include shifts away from agriculture, first to industry, later to services. Within these changes, the effects were in the scale of production and inclusion of human capital. Quatraro (2012) sees the change as a continuous ongoing process, which may be differentiated geographically or in different industries. Structural changes as the outcome depend on the industrial times in which we are. They run around the world and begin in more developed countries, and are initiated by technology. First Industrial Revolution introduced new machines that could be used mostly only for large companies due to their high fixed costs and knowledge needed for operation. It created the need for higher level of competence, which led to the division of labor (Kapás, 2008). These changes led to the creation of organization of work. Chandler (1977) states that with the continuous inventions and growth of organizations from 1850 to 1920 , organizations needed to be transformed. Changes have been made on the basis of technological advances in manufacturing, distribution and strategy. Organizations have tried to use this trend and adapt to innovation. The first managerial functions appeared in the railway and telegraphic industries. Railways demanded managerial coordination and control for safety reasons, especially to create faster steam locomotives.

During the twentieth century, the number of white-collar workers increased. Qualified skills of senior management (managers, professionals, semi-professionals, technical workers), middle and low management (administration, sales) were required (Handel, 2012). In 1989, after the fall of Iron Curtain, a free market began to spread in Eastern Europe. International trade has contributed to US employment growth through exports. Total employment in this sector has increased significantly since 1993 (Occupational Outlook Quartels, 2000). HR has also been transformed over the years. Until the 1990s, HR was still unstable. This discipline was called Personnel and was based on administration and policy camp. In the 1990s, it was already transforming into a HR system. It was based on the PeopleSoft platform that removes work of employees from Personnel of administrative work (such as manager changes, compensation changes, and time off requests) through more efficient technology-based processes (Cook, 2014). In the 1950s, the Human Resources Information System (HRIS) was the first time introduced at General Electric (Bussler \& Davis, 2002). HRIS means human resource management through information technology. The system is used to acquire, store, manipulate, analyze, retrieve, and distribute information about human resources in organizations. The system was designed to reduce HR routine transaction and automate them (Shiri, 2012). In 2014, the third wave of the HRIS system was created. Organizations have replaced cloud-based systems, leading to a self-service HR technology environment that required little or no IT investment. A generation of highly mobile employees has emerged and HR workers have started recruiting through LinkedIn and Facebook. Already in 1900, the idea of creating three educational skills - fostering aspiration, developing reflective conversation, and understanding complexity - was introduced. In the new era of Big data, it is not enough for HR professionals to have only soft skills. Support for HRIS systems is no longer sufficient and experts lack skills (Cook, 2014).

After all, all the revolutions were accompanied by the transformation of the present state into a new, better state. Each revolution has begun with the impulse of technological development in one of the countries (Fuchs, 1968). The technological progress has created a need for change in organizations (Papula \& Volná, 2013) and the demands 
for workers have changed. The closer we get to the present, the technologies are more challenging and complicated, and the need for skills per worker increases. In large corporations, there has been a demand for more information, better administration, financial, accounting, R\&D, planning, strategy, marketing and HR (Handel, 2012; Gažová, 2016).

\section{METHODOLOGY}

The aim of this article is to identify and summarize key common characteristics of previous industrial revolutions based on analysis of secondary data and literature review. Literature review describes in more detail the key characteristics of industrial revolutions, how they arose, how technology was disseminated, what were the working conditions of the employees, what professions prevailed in the given periods. Secondary data from employment, skills, education and technologies are further elaborated and commented in the results and discussion. The literature and secondary data have been summarized from various sources and databases such Emerald, Springer, ProQuest,
ScienceDirect and statistical databases available from European Union, OECD and World Bank. Based on the research results, the article presents important findings regarding common characteristics of industrial revolutions and its impacts on organizational change that can serve as direction for further research, and may lead to lessons learned that can be adopted by organizations in their policies.

\section{RESULTS AND DISCUSSION}

Individual secondary data were divided into 4 categories:

- organizational change and employment;

- organizational change and skills;

- organizational change and education; and

- organizational change and technologies.

\subsection{Organizational change and employment}

From the historical perspective, pre-industrial economy was largely characterized by agricul-

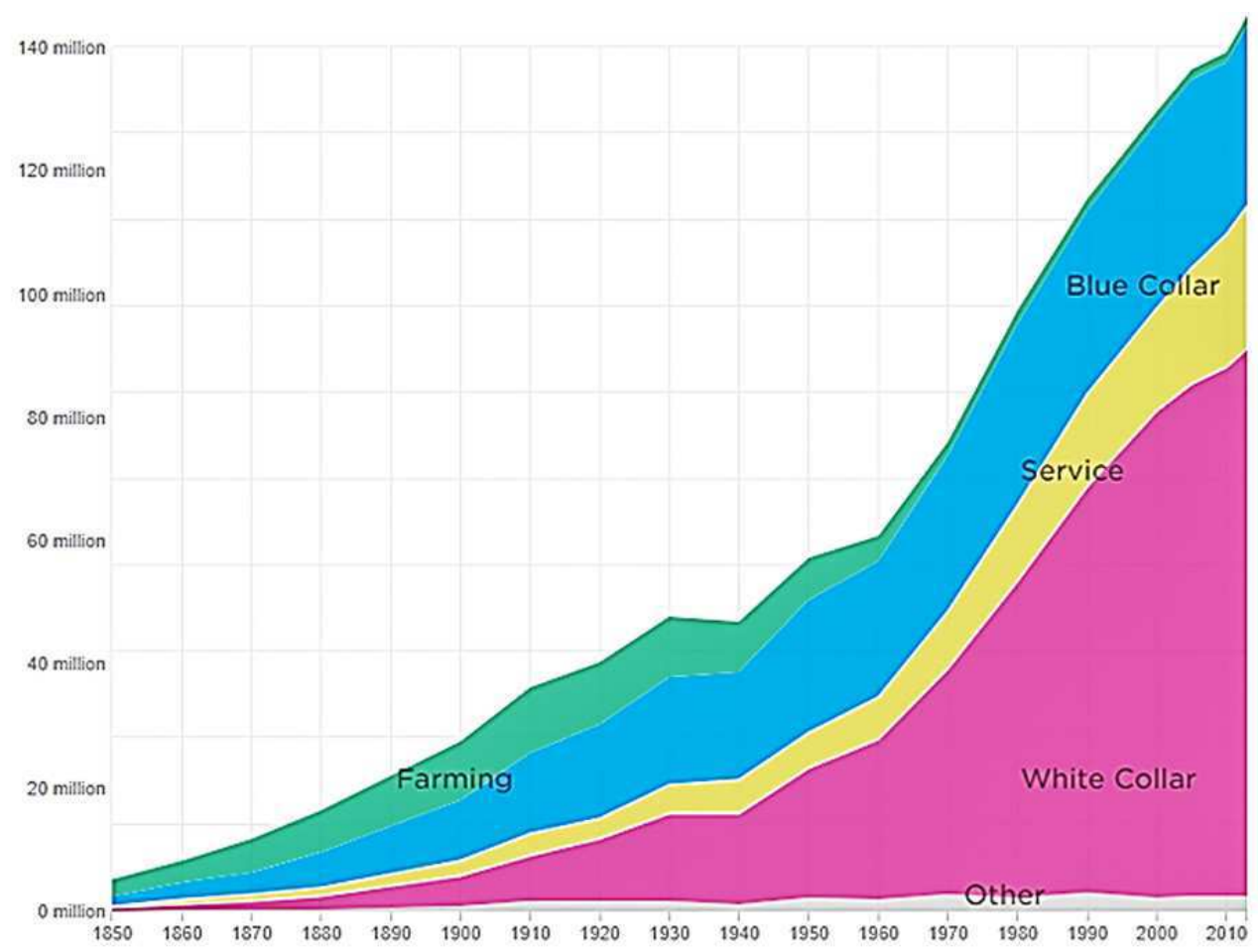

Figure 1. Demand for occupations in 1850-2010, US 
ture as the main sector (Brenner, 1976). The typical pre-industrial worker had to be engaged in many activities, occupations or even industries. With the First Industrial Revolution, the worker became specialized, focused on partial activity in the whole process of conversion of raw material into final product (Deane, 2000).

In 1850, the share of agriculture in total employment was almost $60 \%$ (Lund et al., 2017). At the beginning of the twentieth century, 10 million US residents worked as farmers. By 2010, there were only about 1 million farmers who produced food. As we can see from Figure 1, technologies have removed agricultural positions from the labor market, but on the other hand, they have created jobs in the services sector, blue-collar and white-col- lar (blue-collar includes following positions: machine operators, manual labor, construction jobs, white-collar includes following positions: professional and technical, managerial, sales, clerical jobs, service includes following positions: food service, health care, personal service jobs) (NPR, 2015; Desjardins, 2016). In the early twentieth century, another major change followed - a shift from production to service. Since 1919, employment in the services sector has been higher than in the manufacturing sector. Employment in business services also increased as employment began to develop, such as computer and processing services, advertising, security services (Occupational Outlook Quartely, 2000). According to OECD statistics, the service sector share of jobs increased by $20 \%$ in US, $26 \%$ in UK or $29 \%$ in France.

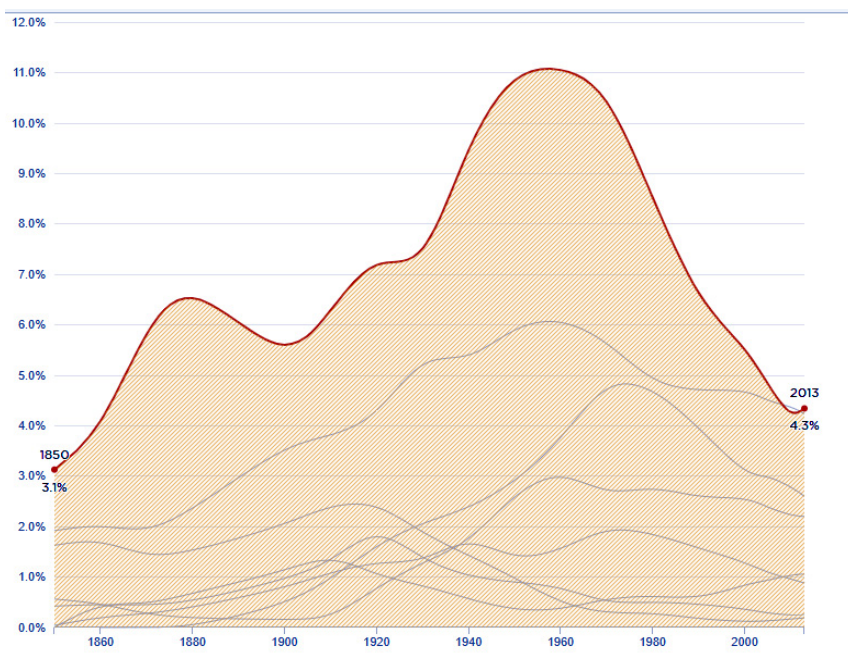

Source: NPR (2015)

Figure 2. Demand for factory workers

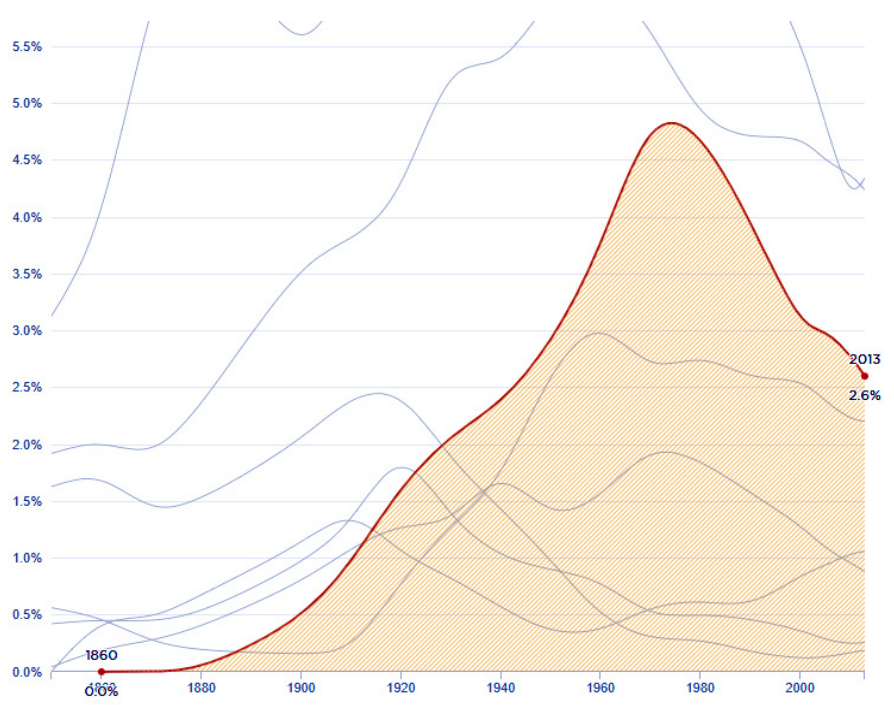

Source: NPR (2015)

Figure 3. Demand for secretaries 


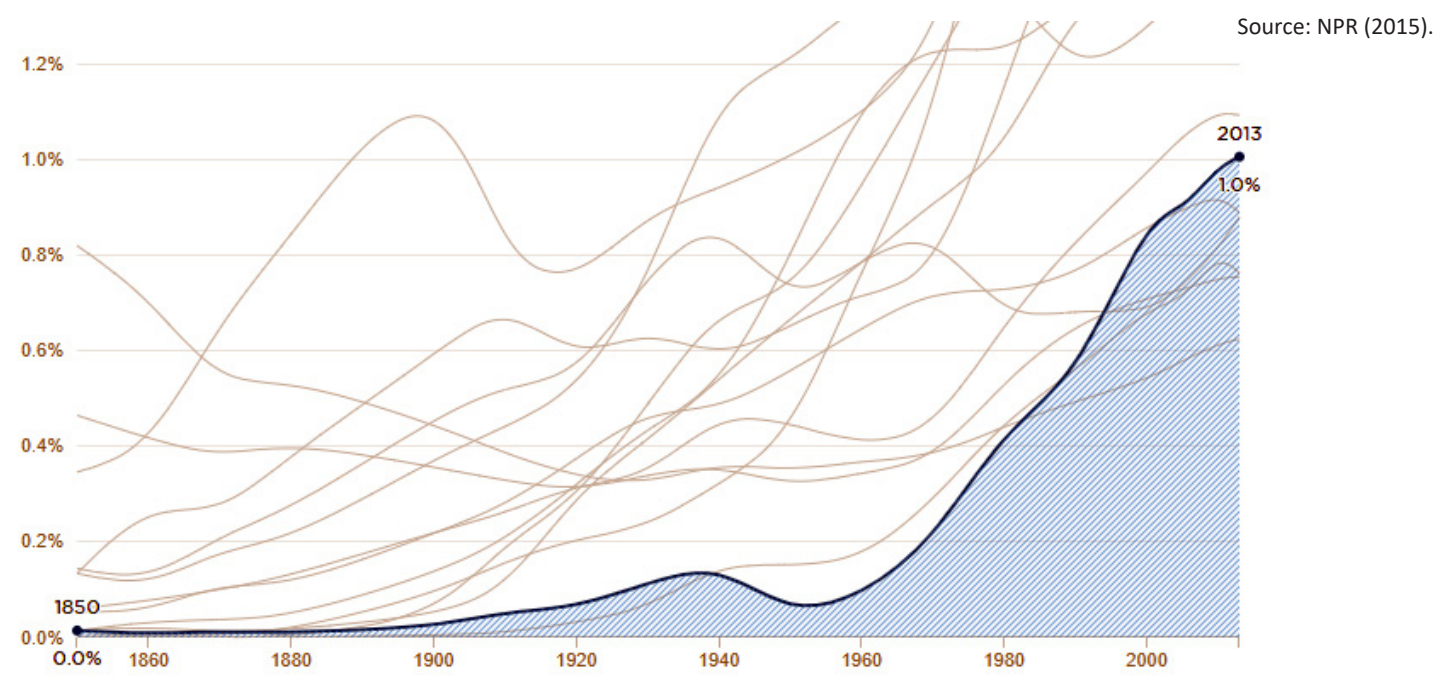

Figure 4. Demand for professors

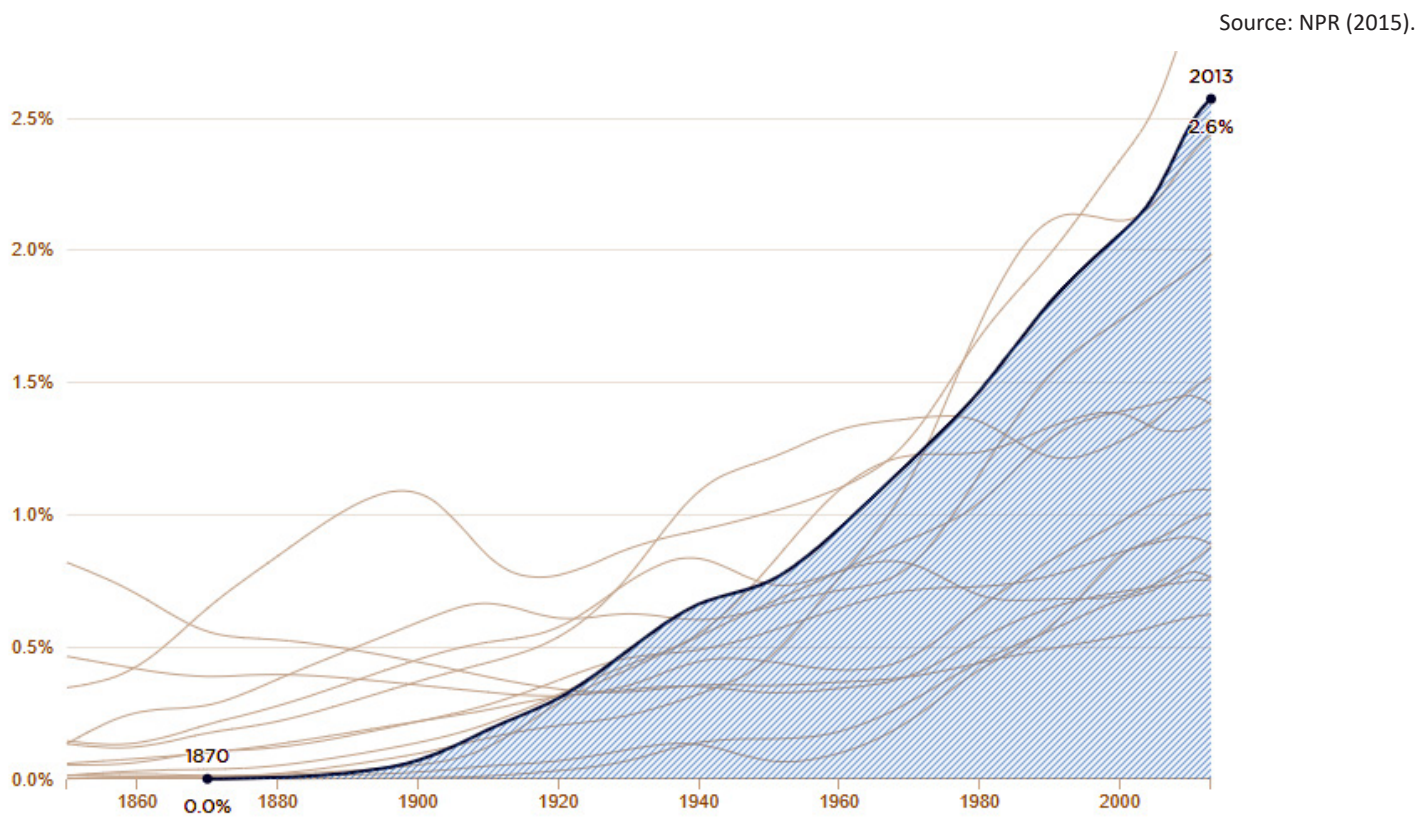

Figure 5. Demand for health care workers

At the beginning of the twentieth century, efficiency assembly-lines were introduced in corporations to produce more products with fewer employees. This trend continued in the next stage of the 20th century (Occupational Outlook Quartely, 2000). Robots and computers have automated many jobs. As we can see in Figure 2, in 1960, the factories in the US employed $11 \%$ of all employees and in 2013 , the factories employed only $4 \%$ (of all employees). This is due to the introduction of new technologies - robots. In Figure 3, we can see that in 1970, 5\% of employees worked as secretaries, in 2013, it was only half. This can be justified by the fact that managers are equally productive without a secretary, because the computer software works instead of secretaries (NPR, 2015; Desjardins, 2016).

We can see changes in the profession of professors (Figure 4) and health care workers (Figure 5). The more automated the factory, the cheaper products were created. So Americans have more money for services - catering, health care and education (NPR, 2015; Desjardins, 2016). Since 1950, health care jobs have increased more than in any comparable industrial sector. This is mainly due to the growing aging population and new technology that has allowed people to cure themselves from diseases that were once fatal (Park, 2016). Employment in 


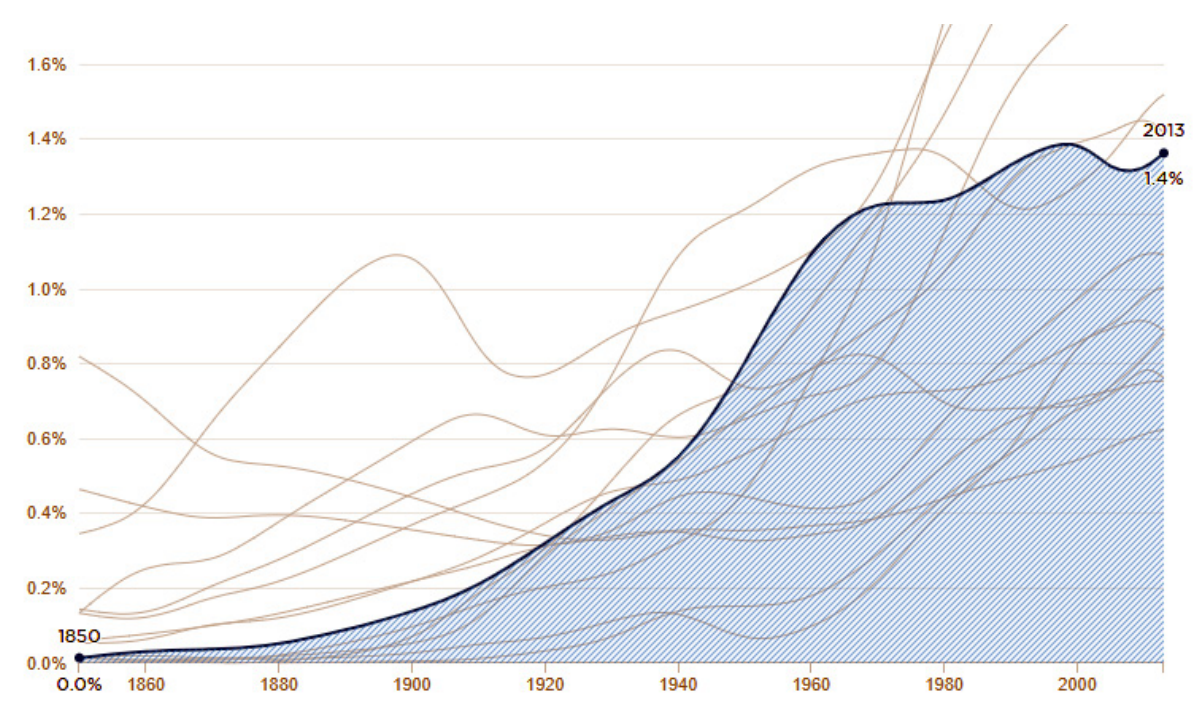

Figure 6. Demand for engineers

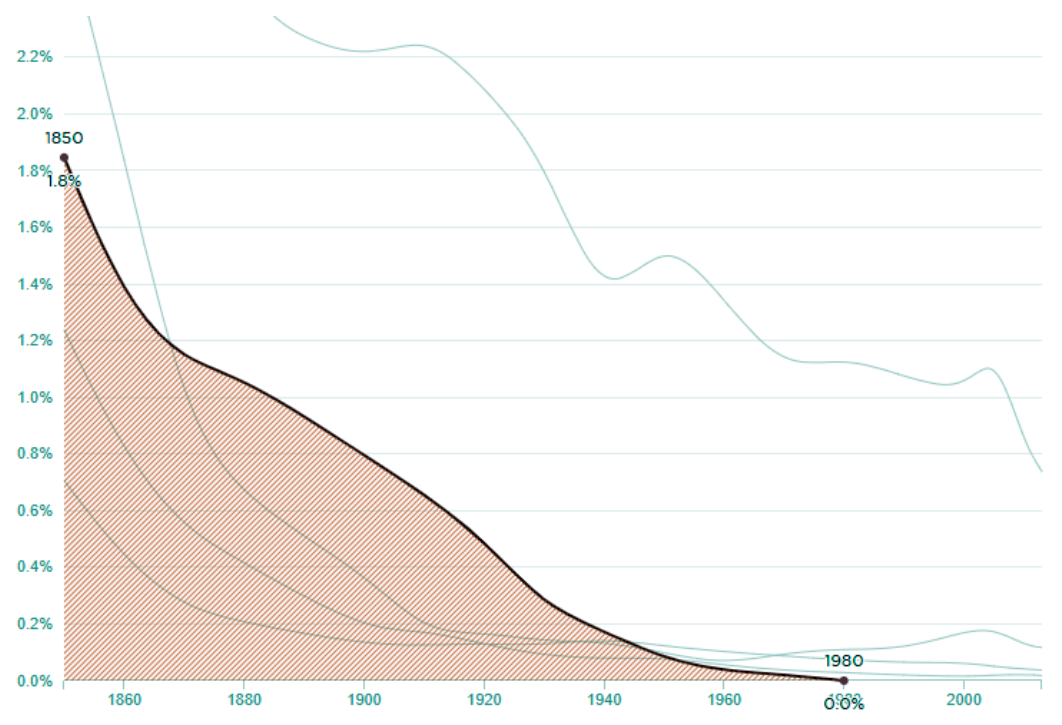

Figure 7. Demand for blacksmith

the health services sector increased by 2.8 million jobs in 1998-2008 (Occupational Outlook Quartels, 2000). In 2013, 2.6\% of health care workers (of all employed) were employed (NPR, 2015; Desjardins, 2016). Teacher work positions increased from 3.75 million (1990) million to over 6 million (2006) (Holzer, 2007). In 2013, the employment of teachers was $1 \%$ (of all employed). These sectors are still labor intensive and increase the number of jobs (NPR, 2015; Desjardins, 2016).

We can see changes in the employment of engineers (Figure 6) and blacksmiths (Figure 7) (NPR, 2015). At the beginning of the 19th centu- ry, the engineering professions were represented only in small numbers. It is estimated that in 1816, there were no more than 30 engineers in the US. Only with the expanding manufacturing industry, between 1880 and 1920, the number of engineers increased by up to $2000 \%$ (from 7,000 to 136,000 ) (Braverman, 1974). Since 1900 ( $0.2 \%$ in Figure 6$)$, the demand for engineers has increased due to the introduction of new technologies (NPR, 2015). In the US in 1970, there were about 1.2 million technical engineers employed in the manufacturing industry, but also by transport communications, as independent consultants, government officials (Braverman, 


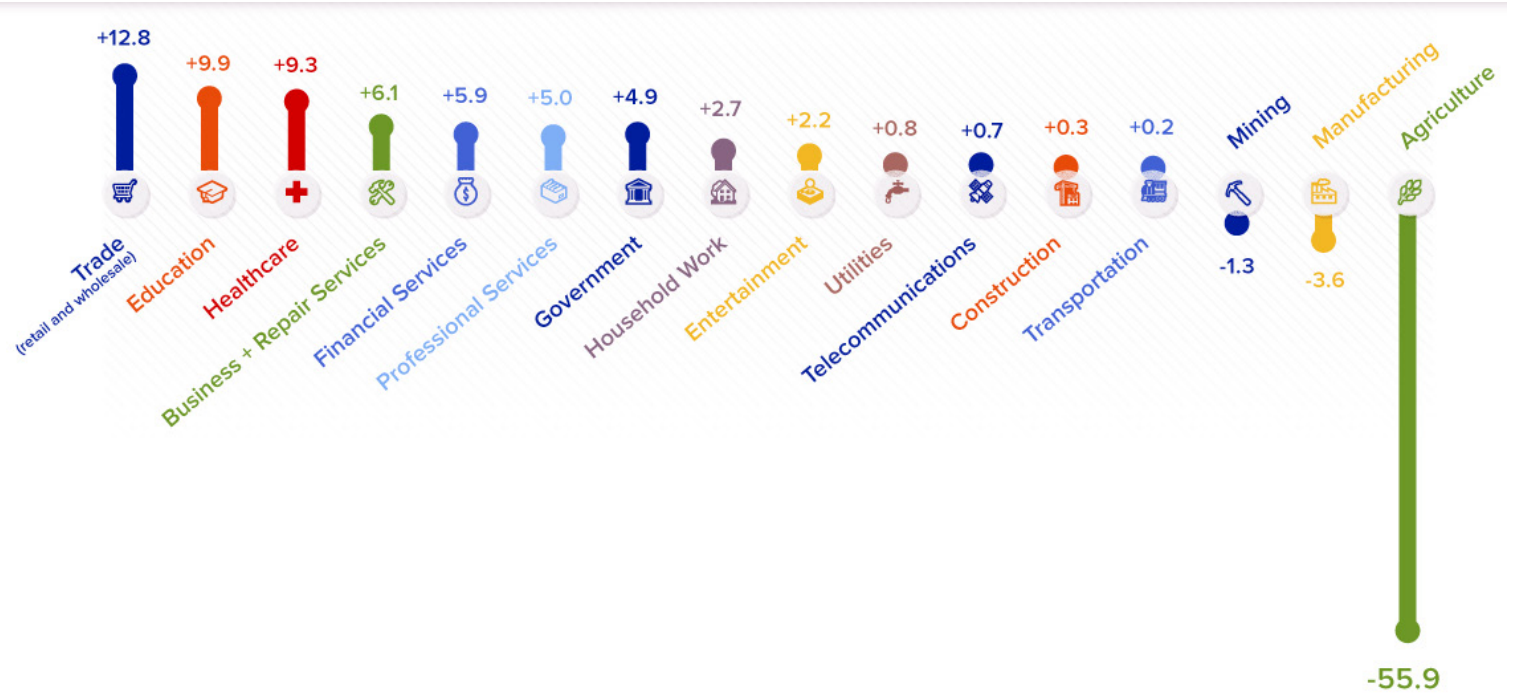

Figure 8. Employment share change in 1850-2015, US

1974). In 2013, up to $1.4 \%$ of US engineers were registered. By contrast, the introduction of technology has significantly reduced the demand for blacksmith work. While in 1850 this profession was request, in 1980, it completely disappeared from the labor market (NPR, 2015).

In Figure 8, we can observe percent changes in occupations between 1850 and 2015 in the US. The biggest percentage difference can be seen in agriculture. On the other hand, the demand for employment in the areas of trade, education, health care, etc. has increased. In the period from 1850 to 2015 , new technologies have weakened the prevailing industries. Jobs in key sectors have disappeared and have been replaced by new jobs in other sectors. With the advent of new technologies, much more jobs have been created than disappeared. The majority new jobs do not belong to the technology manufacturing sector. The introduction of the computer enabled the creation of up to 15.8 million jobs in the US in 1980 (McKinsey Global Institute, 2017). About $90 \%$ of the professions used computers in industries such as call centers, financial analysts, and inventory managers (Lund et al., 2017).

\subsection{Organizational change and skills}

Study by Pleijt et al. (2018) presented findings on the impact of First Industrial Revolution on skills of workers in Britain. The results revealed a negative statistically significant relationship between the number of steam engines per person in a county with share of unskilled workers (Figure 9). This suggests that in comparison to perceiving the industrial revolution as de-skilling (Atack et al., 2008), it was more skill-demanding. The first phase of this industrial revolution was however increasing mostly the low-skilled or middle-skilled employees, where, according to Pleijt et al. (2018), it mostly arised from upskilling the farmers.

Chin et al. (2006) in their study examined the impact of introduction of steam ship during Second Industrial Revolution on the demand on skills in the merchant shipping industry. They have found that the introduction of this technological innovation has led partly to de-skilling, due to change in work positions from skilled and equipped seamen to an engine operation worker. The effect of the de-skilling from the perspective of previously needed occupation was that the number of seamen decreased, however, those who continued on steam ships earned premium compared to new workers on sail vessels (Chin et al., 2006).

Since the late 1970s, companies have begun to invest in technology, research and development, knowledge workers. As a result, the demand for non-skilled workers decreased, it was about $3 / 4$ of the labor force. Demand for highly skilled workers has increased and their wages have increased too (McKinsey Global Institute, 2012). 


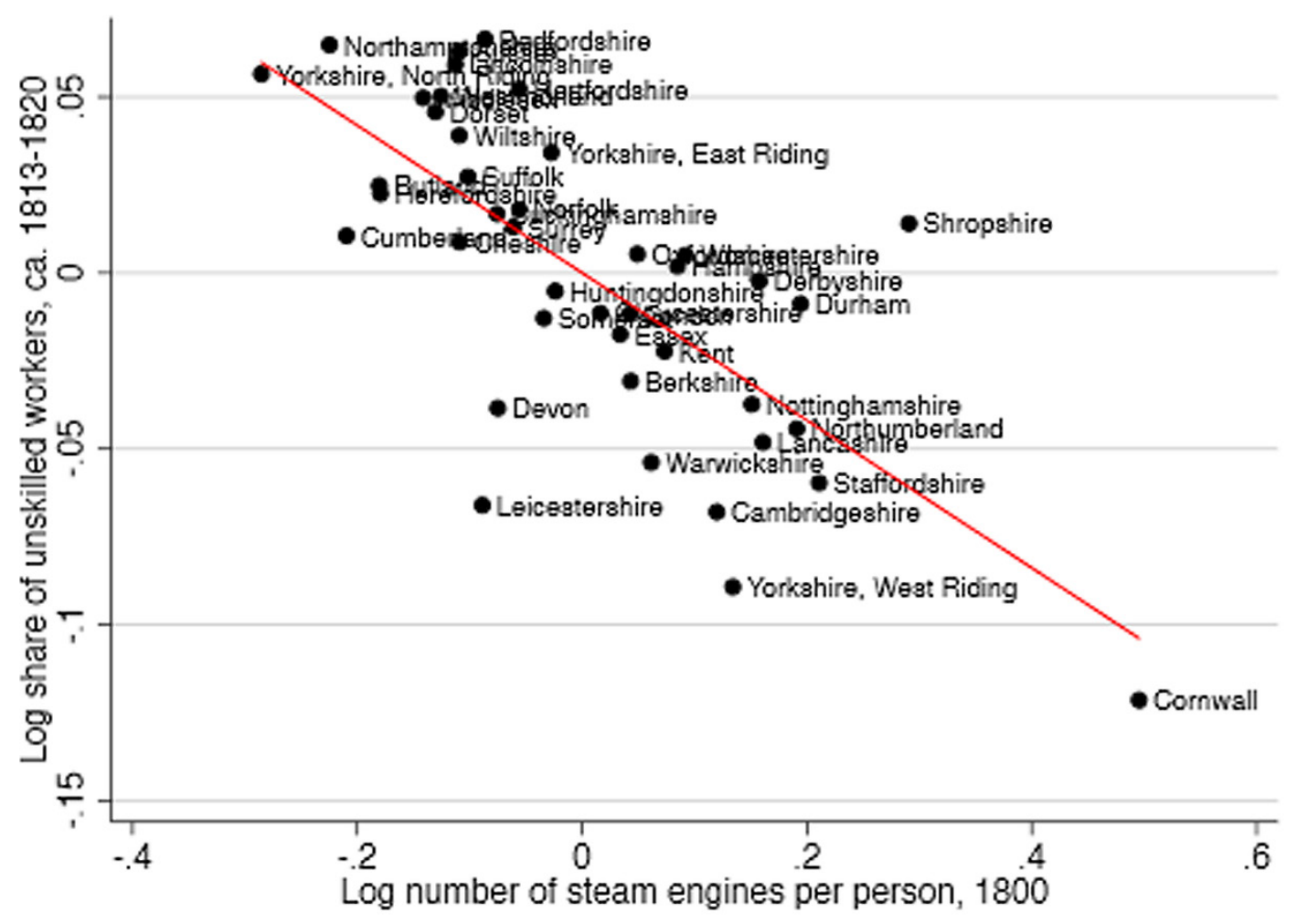

Figure 9. Relation between number of steam engines per person and unskilled workers in Britain

A survey of medium and large enterprises in 1996 found that $19 \%$ of job seekers who had passed the tests had a lack of math skills, reading skills. In 1998 , this percentage increased to $36 \%$. In 2000, jobseekers had a deficit of higher literacy and mathematical skills (Occupational Outlook Quartely, 2000).
Wölfl (2005) explains that in the services sector, the number of highly qualified persons was higher than in the manufacturing sector in 2002. We can observe this phenomenon according to individual country basis in Figure 10. The share of highly qualified jobs in total employment of services is between $15 \%$ and $40 \%$. This

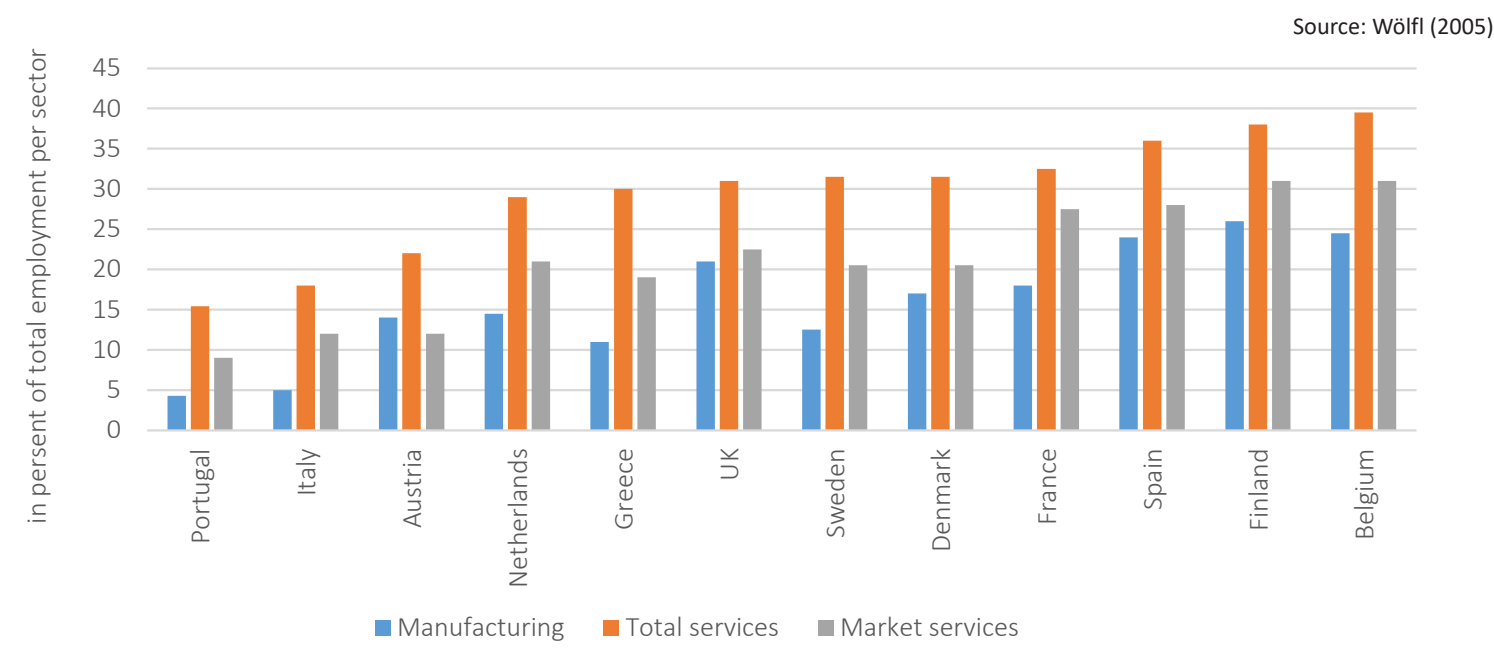

Figure 10. Share of high-skilled employment in total employment per sector, 2002 

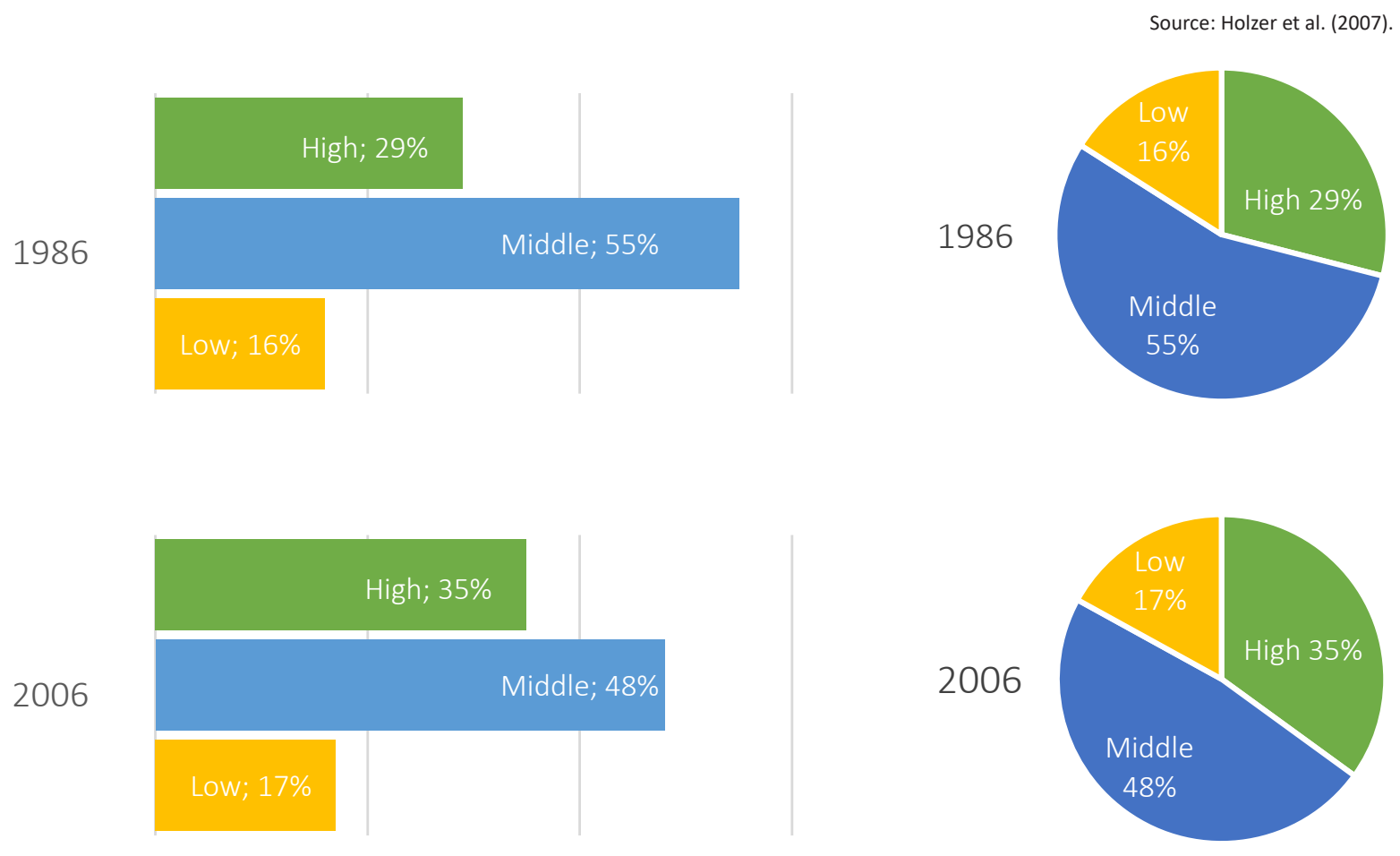

Figure 11. Employment shares by occupational skill level, 1986 and 2006

is because high qualifications are needed especially in non-market services such as education, health care and social services. That in the services sector, the number of highly qualified people is higher than in the manufacturing sector.

Data from 1986 to 2006 presented in Figure 11 show that employment in 2006 has increased since 1986 in the high-skills and low-skills categories, and in the middle-skills category, the demand for jobs has fallen. For example, the number of financial managers has doubled from 406,000 to 1 million. Doctors and medical managers have quadrupled from 127,000 to 551,000 . Sales and office work decreased from $28 \%$ to $25 \%$ (Holzer et al., 2007).

In 2005, the Skills Gap Survey was conducted by National Association of Manufacturers (2005). The survey shows that the American manufacturers experience shortage of qualified employees, especially technical skilled employees. Up to $90 \%$ American companies reported a serious lack of skilled workers (engineers and technicians), $65 \%$ of all respondents said there was a lack of scientists and engineers in the market.
Figure 12 shows the level of qualification of workers in the 27 countries of the European Union + Norway and Switzerland. The level of low skills will not be as requested in the near future as the level of high skills. Employees with middle skills maintain their standard level and will continue to do so. The global economic crisis and the resulting high unemployment caused an excess of human resources with an adequate level of specific and transversal skills (skills that can be used in a wide variety of work settings) (UNESCO-IBE, 2013). The development of employee skills in times of crisis may be due to public sector subsidies to maintain employment (European Commission, 2011).

From Figure 13 we can say that the best jobs of the future will be those green (technical and social skills). Social skills are required in the professions, because developers program their computers to fulfill their role, but they are still not good at listening, empathy, communication and persuasion (Bersin, 2017).

Some authors however pointed out that skilled society does not lead automatically to innovation, rather that the innovation creates the need for skills that create the ground for utilizing and multiplication of innovation (McCloskey, 2011; Howes, 2016). 


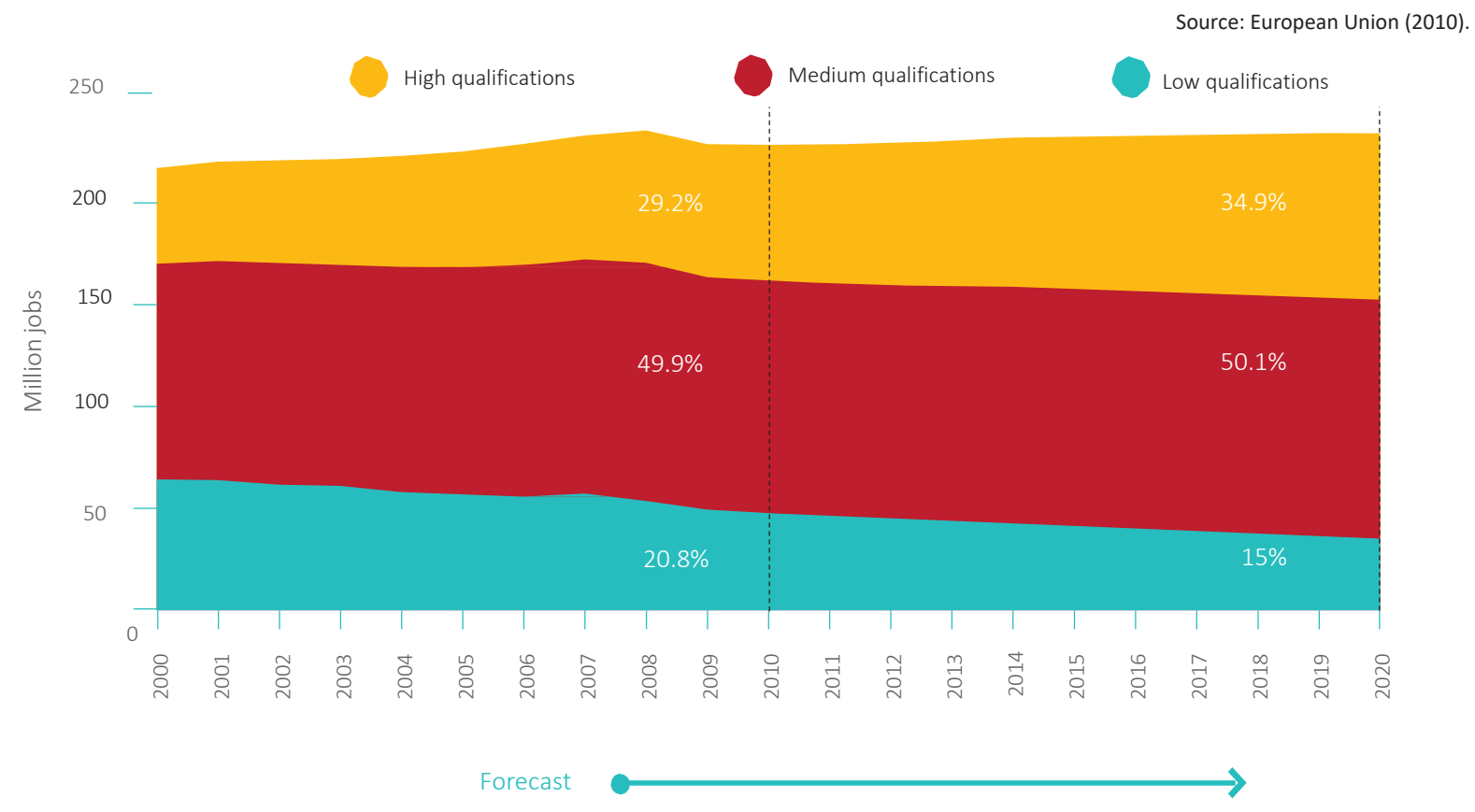

Figure 12. Employment trends by level of qualification, 2000-2020

Source: Bersin (2017).

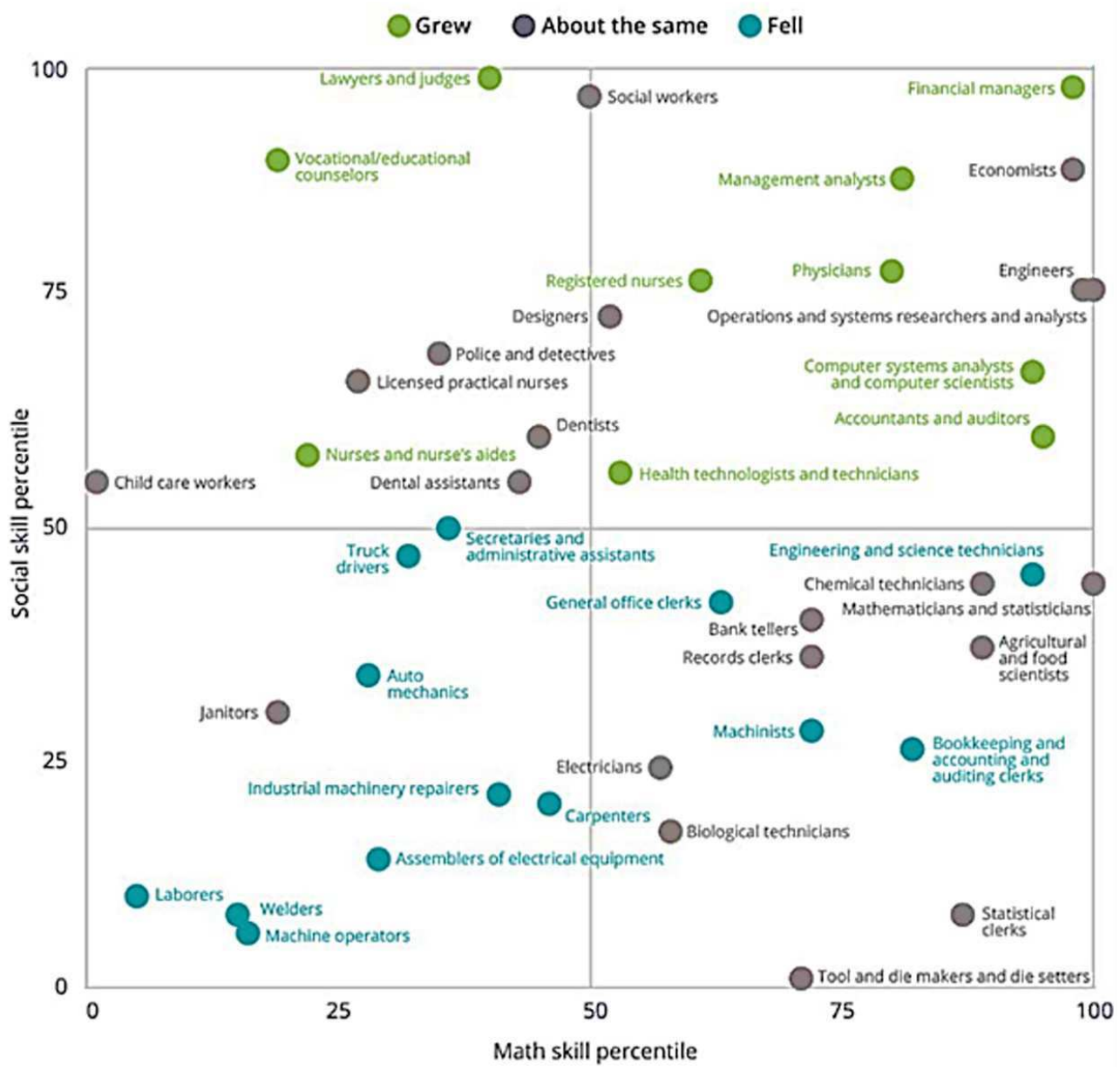

Figure 13. Which jobs require social skills? Change in share of jobs, 1980-2012 


\subsection{Organizational change and education}

Industrial revolution and the beginning of standardization ignited education. While many people were moving to the industrial cities, it created environment for first standardized methods of education, increasing the quality of education that was widespread compared to previous privileged system (Katz, 1987). Due to the upsurge of industry, many industrial schools were established to train necessary skills and knowledge for workers. The need for education arised as well from the shift from agricultural setting of work to non-agricultural. Second Industrial Revolution led to Germany overtake Britain as the most industrialized country. Education thus became critical for industrial Germany. The schools were able to produce many inventors and engineers (Hendrson, 2006). From 1890 to 1900 , technical universities in Germany increased their student intake from 5,361 to 14,734 (Chatzis, 2009).
The data in Table 1 refer to the number of workers (in millions and \%) who achieved education (less than high school, high school, college, BA or higher) in 1980-2020 in the US. In 2000, the percentage of $\mathrm{BA}$ or higher rose to 30 and the projection for 2020 is 33\%. Between 1980 and 2000, the share of high school diploma people and less than high school diploma people dropped from $61 \%$ to $42 \%$ and in 2020 , it should drop to $37 \%$. The percentage of lower educated people decreases between 1980 and 2020 and percentage of higher educated people will increase in 2020 . The forecasts also indicate a slowdown in skills growth. This slowdown may not reach such proportions if more workers decide to retire later and if more young people decide to attend college (Holzer et al., 2007).

In Table 2, we can see very quick development in learning opportunities. Leaders recognize that their internal education programs are lagging behind. Between 1998 and 2002, e-learning was a trend that could be conducted online. Talent man-

Table 1. Actual and projected supply of workers, aged $25+$ by educational attainment

Source: U.S. Bureau of Labor Statistics (2003).

\begin{tabular}{|c|c|c|c|c|c|}
\hline & \multicolumn{3}{|c|}{ Labor force (in millions) } & \multicolumn{2}{|c|}{ Change labor force (in millions) } \\
\hline & 1980 & 2000 & 2020 & 1980-2000 & 2000-2020 \\
\hline Less than high school diploma & 17.3 & 12.0 & 11.9 & -5.3 & -0.1 \\
\hline High school diploma & 31.5 & 37.8 & 40.4 & 6.3 & 2.9 \\
\hline Some college & 13.8 & 32.9 & 39.2 & 19.1 & 6.3 \\
\hline BA or higher & 17.3 & 35.9 & 46.4 & 18.6 & 10.5 \\
\hline \multirow[t]{3}{*}{ Total } & 79.9 & 118.6 & 137.9 & 38.7 & 19.3 \\
\hline & \multicolumn{3}{|c|}{ Percent of workers (\%) } & \multicolumn{2}{|c|}{ Change in percent (\%) } \\
\hline & 1980 & 2000 & 2020 & 1980-2000 & 2000-2020 \\
\hline Less than high school diploma & 21.7 & 10.1 & 8.6 & -11.5 & -1.5 \\
\hline High school diploma & 39.4 & 31.9 & 29.3 & -7.6 & -2.6 \\
\hline Some college & 17.3 & 27.7 & 28.4 & 10.5 & 0.7 \\
\hline BA or higher & 21.7 & 30.3 & 33.6 & 8.6 & 3.4 \\
\hline Total & 100.0 & 100.0 & 100.0 & 0.0 & 0.0 \\
\hline
\end{tabular}

Table 2. The evolution of learning

\begin{tabular}{|c|c|c|c|c|c|}
\hline \multicolumn{6}{|c|}{ Source: Bersin (2017). } \\
\hline & 1998-2002 & 2005 & 2010 & 2017 & 2020 \\
\hline & $\begin{array}{l}\text { E-learning and } \\
\text { blended }\end{array}$ & Talent management & Continuous learning & Digital learning & $\begin{array}{l}\text { Intelligent } \\
\text { learning }\end{array}$ \\
\hline Formats & $\begin{array}{l}\text { Course catalog Online } \\
\text { university }\end{array}$ & $\begin{array}{c}\text { Learning path Career } \\
\text { track }\end{array}$ & $\begin{array}{l}\text { Video, self-authored } \\
\text { Mobile, YouTube }\end{array}$ & $\begin{array}{c}\text { Micro-learning } \\
\text { Real-time video } \\
\text { Courses everywhere }\end{array}$ & \multirow{4}{*}{$\begin{array}{l}\text { Intelligent, } \\
\text { personalized, } \\
\text { machine- } \\
\text { driven }\end{array}$} \\
\hline Philosophy & $\begin{array}{c}\text { Instructional design } \\
\text { Kirkpatrick }\end{array}$ & $\begin{array}{l}\text { Blended learning } \\
\text { Social learning }\end{array}$ & 70-20-10 taxonomies & $\begin{array}{c}\text { Design thinking learning } \\
\text { experience }\end{array}$ & \\
\hline Users & $\begin{array}{c}\text { Self-study } \\
\text { Online learning }\end{array}$ & $\begin{array}{l}\text { Career focused } \\
\text { Lots of topics }\end{array}$ & $\begin{array}{l}\text { Learning on demand } \\
\text { Embedded learning }\end{array}$ & $\begin{array}{l}\text { Everyone, all the time, } \\
\text { everywhere }\end{array}$ & \\
\hline Systems & $\begin{array}{c}\text { LMS as } \\
\text { e-learning platform }\end{array}$ & $\begin{array}{l}\text { LMS as talent } \\
\text { platform }\end{array}$ & $\begin{array}{l}\text { LMS as experience } \\
\text { platform }\end{array}$ & $\begin{array}{c}\text { LMS invisible } \\
\text { Data-driven, mobile }\end{array}$ & \\
\hline
\end{tabular}




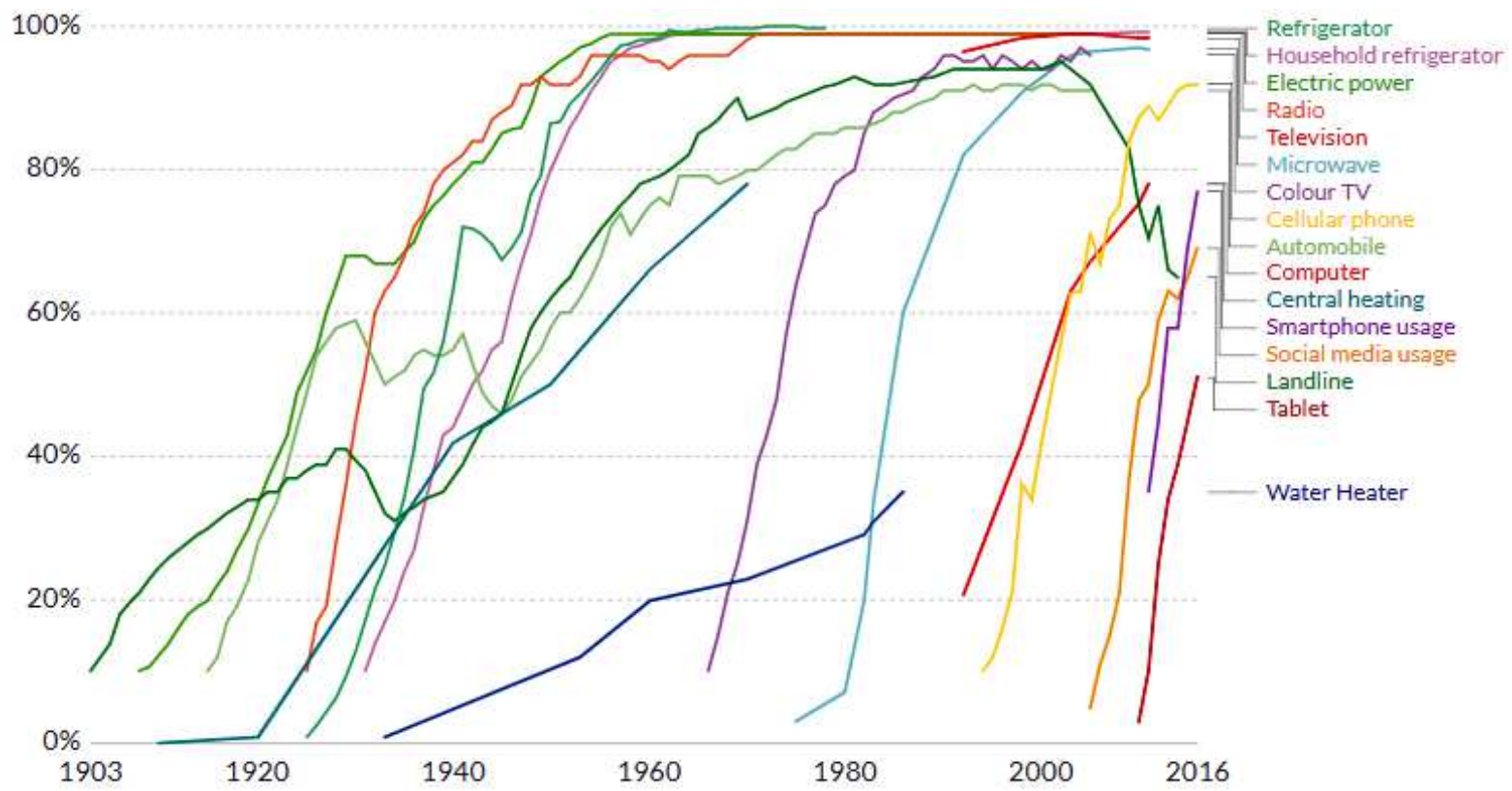

Figure 14. Technology adoption in US households

agement skills were required in 2005 , continuous learning in 2010, digital learning in 2017, and intelligent learning will be required in the next period. Requirements and systems are more demanding every year. In 2020 , we will be trained by personalized and machine-driven systems (Bersin, 2017).

\subsection{Organizational change and technologies}

First Industrial Revolution, known also as British industrial revolution, was brought by acceleration of innovation. While economic outputs driven by innovation were mostly created at the end of the period of industrial revolution (1850s), many innovations had first appearances or first concepts even a century before (Howes, 2016). Further, the pace of adaptation to new technologies, for example, steam engines, was affected by regional differences (Hudson, 1989).

In Figure 14, we can observe the spread and acceptance of individual technologies, as they were adopted in US homes from 1903 to 2016. For example, US households have started to use landline since 1903. The number of users grew at a slow pace, until in the year 2002, landline was used by up to $95 \%$ of households. Nowadays, this trend is declining and only about $65 \%$ of households have used landline in 2014. On the other hand, mobile phones started to be used by American households in 1994, it was $10 \%$. The number of users in this case grew at a faster pace and in 2016, 92\% of households already used their mobile phones. Smartphone was used in the US in 2011 by only $35 \%$ of population and the number of users rose to 77\% by 2016 (Ritchie et al., 2019).

Robots as technological innovations are often discussed in the context of current era. However, the idea of robot was first introduced in 1920 by Karel Čapek (Čapek, 2004), while first electronic autonomous robots where created in starting late 1940s, while, for example, General Motors have bought a robot for production already in 1961 (Climent, 2015). Not only robots are presented as technological trend for future, but also artificial intelligence. Similarly, however, Edmund Berkeley publishes Giant Brains: Or Machines That Think in 1949 in which he describes characteristics of artificial intelligence in a form as it is being developed today (Berkeley, 1949). Since then, many technologies using artificial intelligence were invented, however, not mass implementation was conducted.

It can be seen that the pace of innovation adaption by society has been increasing over time, however, the time before first concepts or partial inventions till the actual innovation and the demand for it on the market has remained much longer. 


\section{CONCLUSION}

Common feature of implementation in all industrial revolutions is the transition from centralization (steam engine, data processing center) to decentralization (electric motor, stand-alone computer, and work station). Some technologies were spreading very quickly due to the increasing demand, such as internet or smartphone, however, many technologies experienced stagnation due to the non-existent market for its utilization. Industrial revolutions were bound mainly to the phase of invention, which, however, did not directly affect the utilization of these inventions, this was rather slow. For example, the First Industrial Revolution took 120 years to spread across Europe (Schwab, 2017). Nowadays, the boundaries for spreading are overcome by interconnections in the world and easier access to technologies, however, the utilization of most inventions is linked to other inventions that may support its dissemination.

The key finding of our retrospective study is the continuous increase in demand for service workers that occurred during previous industrial revolutions. Not only that, but the pace has been increasing and the proportion of services jobs to manufacturing has been increasing with multiples. Manufacturing jobs, such as machine operators, often occupied by low- to middle-skilled employees, did not disappear, while during the technological shifts, these positions were filled by reskilled or imported human capital. On the other hand, many service jobs created were new and based on a need for wider knowledge.

Following on the previous finding, the second finding of the analysis of secondary data brings insight on the role of education during industrial revolution. Education played a major role regarding technological change, while demand for middle-skilled was decreasing and increasing for the high-skilled. Countries that were able to produce high-skilled people could not only invent, but also adapt to new technologies sooner than others. Education played a major role not only in the manufacturing jobs, but also in the service jobs, which is in line with results of Sugayama's (1992) study.

Our analysis has shown that the pace of changes and its impact is different for development and for implementation of innovations. In line with fundamentals of Chinese medicine, the development phase seems to be stimulated by insufficiency, while the surplus creates stagnation. Stagnation arises from the slow adaptation of management to changes compared to the pace of inventions. On the one hand, companies were able to quickly recognize the need for specific jobs regarding new technologies, which, however, produced employees with only specific skills that were not applicable to other technological shifts. In this context, revolutions were often seen in as a reason for de-skilling of population. While with respect to the longer periods of technological change in the previous times, it could be sufficient for organizations to have specifically skilled employees, it will be not applicable for the current pace of change and high competitiveness. While industrial revolutions have created more jobs over time, from the microeconomic perspective, some positions will still need to disappear, but it takes some time till technologies replace themselves and thus the jobs actually become redundant.

The final outcome of our analysis is the understanding that technologies are not the driver of economic growth, they are a tool that needs to be utilized by companies to create this growth. This was shown by the adaptation approaches of growing countries during industrial revolution regarding their policies for education or changes in managerial practices. Companies that have adopted new approaches in utilization of human capital were able to build on their competitiveness for a long time. While the managerial practice has been evolving from "economies of scale of people" into more personal approach, the previous revolutions have shown that with the new dramatic changes, the managerial practice needs to adopt as much as, for example, manufacturing processes. The further discussion on impacts of current industrial revolution should thus focus on the expected changes in managerial practices, especially with the large proportion of jobs created in services, where the traditional view of services as immune to foreign competition is no longer existent. 
The purpose of this article was to return the retrospective view and opinions of past authors to the current discussion that can enrich and complement the research that is being conducted on the Fourth Industrial Revolution, which can help other authors interpret their research results. The contribution of this article is completing the ongoing scientific debate with this retrospective historical context.

\section{ACKNOWLEDGEMENT}

This research was supported and funded by APVV-17-0656 titled "Transformation of Paradigm in Management of Organizations in the Context of Industry 4.0".

\section{REFERENCES}

1. Agostini, L., \& Filippini, R. (2019). Organizational and managerial challenges in the path toward Industry 4.0. European Journal of Innovation Management, 22(3), 406-421. https://doi.org/10.1108/ EJIM-02-2018-0030

2. Atack, J., Bateman, F., \& Margo, R. A. (2008). Steam Power, Establishment Size, and Labor Productivity Growth in Nineteenth Century American Manufacturing. Explorations in Economic History, 45, 185 98. Retrieved from https:// www.academia.edu/21950286/ Steam_Power_Establishment_ Size_and_Labor_Productivity_Growth_in_Nineteenth_Century_American_Manufacturing

3. Basl, J. (2017). Pilot study of readiness of Czech companies to implement the principles of Industry 4.0. Management and Production Engineering Review, 8(2), 3-8.

4. Berkeley, E. C. (1949). Giant Brains or Machines That Think (270 p.). New York: John Wiley and Sons, Inc. Retrieved from https://archive.org/details/in.ernet. dli.2015.233530/page/n5

5. Bersin, J. (2017). Catch the wave: The 21st-century career. Retrieved from https://www2.deloitte.com/ insights/us/en/deloitte-review/ issue-21/changing-nature-ofcareers-in-21st-century.html

6. Braverman, H. (1974). Labor and Monopoly Capital. New York: Monthly Review.

7. Brenner, R. (1976). Agrarian Class Structure and Economic
Development in Pre-Industrial Europe. Past and Present, 70, 3075. Retrieved from http://www. jstor.org/stable/650345

8. Bussler, L., \& Davis, E. (2002). Information system: The quiet revolution in human resource management. Journal of Computer Information System, 19(3), 41-50.

9. Čapek, K. (2004). R.U.R. (Rossum's universal robots). New York: Penguin Books.

10. Chandler, A. D. Jr. (1977). The Visible Hand: The Managerial Revolution in American Business. Cambridge: Harvard University Press.

11. Chandler, A. D. Jr. (1990). Scale and Scope: The Dynamics of Industrial Capitalism (800 p.) Cambridge: Harvard University Press.

12. Chatzis, K. (2009). Coping with the Second Industrial Revolution: fragmentation of the French engineering education system, 1870 s to the present. Engineering Studies, 1(2), 79-99. http://dx.doi. org/10.1080/19378620903005675

13. Chin, A., Juhn, C. H., \& Thompson, P. (2006). Technical Change and the Demand for Skills during the Second Industrial Revolution: Evidence from the Merchant Marine, 1891-1912. The Review of Economics and Statistics, 88(3), 572-578

14. Climent, J. (2015). Postwar America: An encyclopedia of social, political, cultural, and economic history. New York: Routledge.
15. Comin, D., \& Hobijn, B. (2004). Cross-country technology adoption: Making the theories face the facts. Journal of Monetary Economics, 51(1), 39-83.

16. Cook, I. (2014). Five Signs Your Company's HR Strategy is Stuck in the 90s. Retrieved from https:// www.visier.com/clarity/hr-strategy-is-stuck-in-the-90s/

17. De Pleijt, A., Nuvolari, A., \& Weisdorf, L. J. (2018). Human Capital Formation during the First Industrial Revolution: Evidence from the Use of Steam Engines (CEPR Discussion Papers No. 12987). Retrieved from https://ideas.repec.org/p/cpr/ ceprdp/12987.html

18. Deane, P. (2000). The first industrial revolution. Cambridge: Harvard University Press.

19. Deloitte. (2005). 2005 Skills Gap Report - Survey of the American Manufacturing Workforce. Washington, DC: Deloitte Development LLC.

20. Desjardins, J. (2016). How Machines Destroy and Create Jobs. Retrieved from https://www.visualcapitalist.com/how-machinesdestroy-and-create-jobs/

21. Desjardins, J. (2019). Visualizing 150 Years of U.S. Employment History. Retrieved from https:// www.visualcapitalist.com/visualizing-150-years-of-u-s-employment-history/

22. Eden, L. (2018). The Fourth Industrial Revolution: Seven Lessons from the Past (pp. 15-35). In R. van Tulder, A. Verbeke, \& 
L. Piscitello (Eds.), International Business in the Information and Digital Age (Progress in International Business Research, Volume 13). Emerald Publishing Limited,

23. European Commission. (2011). Transferability of Skills across Economic Sectors: Role and Importance for Employment at European Level. Luxembourg: Publications Office of the European Union.

24. European Union. (2010). New Skills for New Jobs: Action Now. Retrieved from https://ec.europa. eu/social/BlobServlet?docId $=4508$ \&langId=en

25. Fayol, H. (1916). Administration industrielle et Generale. Paris: Dunod.

26. Fuchs, V. R. (1968). The Service Economy (266 p). New York and London: Colombia University Press.

27. Gazova, A., Papulova, Z., \& Papula, J. (2016). The application of concepts and methods based on process approach to increase business process efficiency. Procedia Economics and Finance, 39, 197-205.

28. Handel, M. (2012). Trends in Job Skill Demands in OECD Countries (OECD Social, Employment and Migration Working Papers, No. 143). OECD Publishing. http:// dx.doi.org/10.1787/5k8zk8pcq6tden

29. Hendrson, W. O. (2006). The Industrial Revolution on the Continent: Germany, France, Russia, 1800-1914. Abingdon, Oxon: Routledge,

30. Holzer, H. J., \& Lerman, R. I. (2007). America's forgotten middleskill jobs. Washington, DC: The Workforce Alliance. Retrieved from https://www.urban.org/ research/publication/americasforgotten-middle-skill-jobs/view/ full_report

31. Howes, A. (2016). The Relevance of Skills to Innovation during the British Industrial Revolution, 1651 1851 (Working Paper). Retrieved from http://eh.net/eha/wp-content/uploads/2016/08/Howes.pdf
32. Hudson, P. (Ed.) (1989). The regional perspective. In Regions and industries: a perspective on the industrial revolution in Britain. Cambridge: Cambridge University Press.

33. Jensen, M. C. (1993). The Modern Industrial Revolution, Exit, and the Failure of Internal Control Systems. The Journal of Finance, 48, 831-880. http://dx.doi. org/10.1111/j.1540-6261.1993. tb04022.x

34. Kapás, J. (2008). Industrial revolutions and the evolution of the firm's organization: an historical perspective. Journal of Innovation Economics and Management, 2(2), 15-33.

35. Katz, M. B. (1987). Reconstructing American Education. Cambridge, MA: Harvard University Press.

36. Kuznets, S. (1973). Modern Economic Growth: Findings and Reflections, American Economic Review, 63, 247-258.

37. Lamoreaux, N. R. (1985). The Great Merger Movement in American Business, 1895-1904. Cambridge: Cambridge University Press.

38. Lund, S., \& Manyika, J. (2017). Five lessons from history on AI, automation, and employment. Retrieved from https://www. mckinsey.com/featured-insights/ future-of-work/five-lessons-fromhistory-on-ai-automation-andemployment

39. Mathias, P. (2001). The first industrial nation. An economic history of Britain 1700-1914 (493 p.). London; New York: Routledge.

40. McCloskey, D. (2011). Bourgeois Dignity: Why Economics Can't Explain the Modern World (588 p.). University of Chicago Press.

41. McKinsey Global Institute. (2012). The world at work: Jobs, pay and skills for 3.5 billion people. Retrieved from https://www. mckinsey.com/featured-insights/ employment-and-growth/theworld-at-work

42. McKinsey Global Institute. (2017). Jobs lost, jobs gained: workforce transition in a time of automation.
Retrieved from https://www. mckinsey.com/ /media/mckinsey/ featured\%20insights/Future\%20 of $\% 20$ Organizations/What $\% 20$ the $\% 20$ future $\% 20$ of $\% 20$ work $\% 20$ will\%20mean $\% 20$ for\%20jobs\%20 skills\%20and\%20wages/MGIJobs-Lost-Jobs-Gained-ReportDecember-6-2017.ashx

43. Mokyr, J., \& Strotz, R. H. (2000). The Second Industrial Revolution, 1870-1914. Retrieved from https:// pdfs.semanticscholar.org/d3fc /63c43a656f01f021fb79526d9 ba3b25f6150.pdf?_ga=2.74899602.122092665.1559886019686518374.1559886019

44. NPR. (2015). How Machines Destroy (And Create!) Jobs, in 4 Graphs. Retrieved from https://www.npr.org/sections/ money/2015/05/18/404991483/ how-machines-destroyand-create-jobs-in4-graphs? $\mathrm{t}=1553695437298$

45. Occupational Outlook Quartely. (2000). Futurework: Trends and challenges for work in the 21st centry. Retrieved from https:// www.bls.gov/careeroutlook/2000/ Summer/art04.pdf

46. OECD. (n.d.). Quarterly Labor Force Statistics, various issues, and Labor Force Statistics, 1985-2005.

47. Papula, J., \& Papulová, Z. (2014). Konkurenčné stratégie: tradičné prístupy vs. nové pohlady a techniky. Bratislava: Wolters Kluwer.

48. Papula, J., \& Volná, J. (2013). Core Competence for Sustainable Competitive Advantage, Multidisciplinary Academic Research. Praha: MAC Prague consulting.

49. Park, H. A. (2016). Are We Ready for the Fourth Industrial Revolution? Yearbook of Medical Informatics, 25(1), 1-3. http:// dx.doi.org/10.15265/IY-2016-052

50. Perkin, H. (1996). The Third Revolution: Professional elites in the modern world. London: Routledge.

51. Quatraro, F. (2012). The Economics of Structural Change in Knowledge (224 p.). London: Routledge. Retrieved from https://halshs. 
archives-ouvertes.fr/file/index/ docid/727628/filename/The_Economics_of_Structural_Change_in_ Knowledge_2011-09-10.pdf

52. Rifkin, J. (2012). The Third Industrial Revolution: How the Internet, Green Electricity, and 3-D printing are Ushering in a Sustainable Era of Distributed Capitalism. Retrieved from http://www.worldfinancialreview. $\mathrm{com} /$ ?p=2271

53. Ritchie, H., \& Roser, M. (2019). Technology Adoption. Retrieved from https://ourworldindata.org/ technology-adoption

54. Schwab, K. (2017). The Fourth Industrial Revolution. World Economic Forum, Geneva, Switzerland.

55. Shiri, S. (2012). Effectiveness of Human Resource Information
System on HR Functions of the Organization - A Cross Sectional Study. US-China Education Review, 9(A), 830-839. Retrieved from https://pdfs.semanticscholar.org/4032/bc93604b44dabae1ba2ddefc8a35577116b7.pdf

56. Stearns, P. N. (2012). The Industrial Revolution in World History (4th ed.). New York: Routledge.

57. Sugayama, S. (1992). Whitecollar workers in the industrial revolution. Keiei Shigaku (Japan Business History Review), 27(4), 1-31. http://dx.doi.org/10.5029/ bhsj.27.4_1

58. Taylor, F. W. (1911). Principles of scientific management. New York: Harper \& Row.

59. Tortorella, G. L., \& Fettermann, D. (2017). Implementation of Industry 4.0 and lean production in Brazilian manufacturing companies. International Journal of Production Research, 56(8), 2975-2987. http://dx.doi.org/10.1 080/00207543.2017.1391420

60. U.S. Bureau of Labor Statistics (BLS). (2006). Occupational Projections and Training Data. Labor Dept., Labor Statistics Bureau.

61. UNESCO-IBE. (2013). Glossary of Curriculum Terminology. Retrieved from http://www.ibe. unesco.org/fileadmin/user_upload/Publications/IBE_GlossaryCurriculumTerminology2013 eng.pdf

62. Wölfl, A. (2005). The Service Economy in OECD Countries (STI Working Paper No. 2005/3). Paris: OECD Publishing. 